\title{
The Single Minute Exchange of Die Methodology in a High-Mix Processing Line
}

- Filla Jan

\begin{abstract}
Because of turbulence in the economic environment, enterprises must react flexibly to the changing demands of their customers. Thus, a changeover process is required. If an enterprise has a large product portfolio, there are basically only two process options; to integrate production into large batches or to change the production programme frequently. Frequent changes associated with the changeover process of machinery are optimized by using the SMED method. The main goal of this paper is to apply SMED (Single Minute Exchange of Die) to a High-Mix processing line. The case study is undertaken in a flat glass processing company which manufactures hundreds of types of products. The results of the case study demonstrate that it is possible to save up to $30 \%$ annually of the time currently spent on changeovers.
\end{abstract}

Keywords: Changeover, SMED, Single Minute Exchange of Die, High-Mix Processing Line

JEL Classification: $M 11$

\section{INTRODUCTION}

The production activities of various companies are often complicated by specific requirements of their customers. Companies across the production sector need to satisfy customer demands to remain competitive and profitable (Mašín \& Vytlačil, 2000). Ferrdás and Salonitis (2013) see the solution of this issue in the implementation of lean manufacturing tools and also through the use of customer-pull-based production, which should allow for the satisfaction of most customer requirements. Customer-pull-based production is closely related to the changeover of machinery. McIntosh et al. (2007) and Cakmakci (2009) state that the problem with changeover processes can be solved primarily by using two different approaches. The first approach is to integrate production into larger batches. King (2009) claims that if the changeover process is too long, expensive, or both, then there is an effort to manufacture in large batches instead of changing frequently to different types of products. The result of this solution is minimizing the machine downtime caused by changeovers. The second approach involves the frequent change of the production programme, i.e. frequent changeover of the machinery. The changeover process itself is mostly optimized by using the SMED method, defined by Shigeo Shingo in the 1950s, which is described in detail in the subsequent literature review (Shingo, 1985).

\section{THEORETICAL BACKGROUND}

The Single Minute Exchange of Die (SMED) method was proposed in the late 1950s by Shingo (1985) during his work in the Mazda production plant. The method itself is mainly focused on the significant reduction of the time required for the changeover of machinery, but there are 
also many applications of this method for different purposes; e.g. McIntosh et al. (2001) describe similarities between changeover and maintenance tasks. They admit that integrating maintenance and changeover is likely to be difficult, but state that successful integration of these two methods is possible.

As Fig. 1 depicts, Shingo (1985) defined the SMED method as a three-step process:

- Separating the internal and external setups

- Converting the internal setup to external

- Streamlining all operations within both kinds of setups

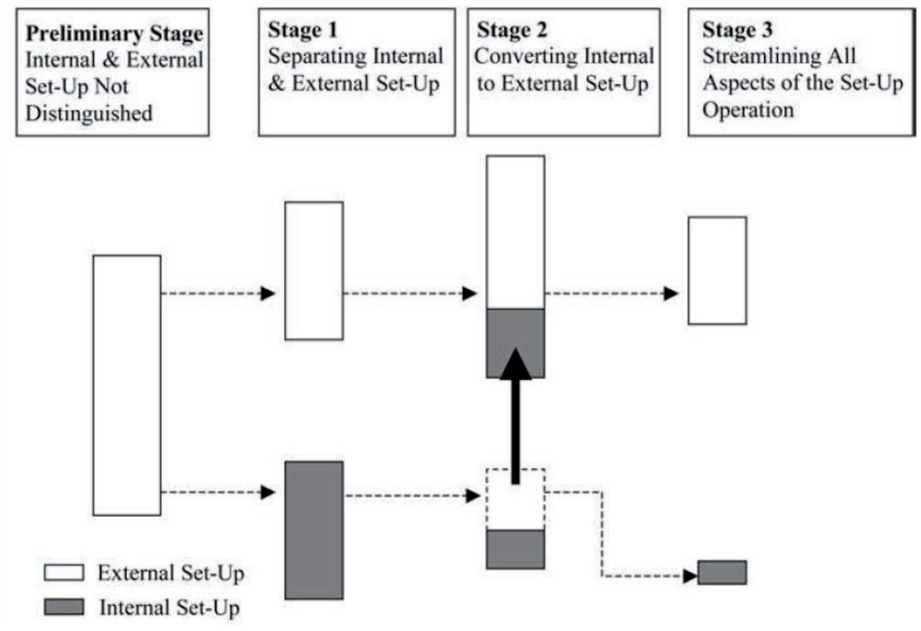

Fig. 1 - Original SMED conceptual stages (Moxham \& Greatbanks, 2001)

Originally, the SMED method was generally used to reduce changeover process time, and it has been promoted by many lean managers and academics (McIntosh et al., 2007). This concept is perceived as the best way to reduce industrial changeover times. Nevertheless, there have been many modifications of the original SMED concept. McIntosh et al. (2001) suggested the integration of the SMED method and TPM (Total Productive Maintenance). According to Perinić, Ikonić, and Maričić (2009), the application of the SMED method should be supported by a simultaneous implementation of $5 \mathrm{~S}$. The need to implement the basics of visual management and proper workplace organization has also been recognized by other authors (Bikram \& Khanduja, 2010; Moxham \& Greatbanks, 2003).

The low-cost/no-cost solution (Culley et al., 2003; Cakmakci, 2009) and a new design solution (McIntosh et al., 1996) are two approaches which are often used to reduce the duration of internal and external activities. Nowadays, the low-cost/no-cost solution is advocated by most companies and experts. The main principles behind this solution are organizational workflow changes (Culley et al., 2003; Cakmakci, 2009), teamwork support, the application of visual management (Perinić, Ikonić, \& Maričić, 2009), and minor technical modifications of machinery (Sharma, 2001). 
In Cottyn et al. (2011), Sheri and Bohn (2005), and Palanisamy and Siddiqui (2013) the authors claim that the synergy of application of industrial engineering methods and modern information technologies and systems may have a positive influence on production activities. Cottyn et al. (2011) state that the application of lean manufacturing methods can be supported by the application of information systems, such as MES - Manufacturing Execution Systems - and also that MES can maintain the results achieved by the implementation of industrial engineering methods mainly by ensuring that selected processes are executed in a standardized way. Palanisamy and Siddiqui (2013) propose that integration of the SMED method and MES solves problems with scheduling set-up activities on multiple machines; they also mention that the implementation of MES allows effective redistribution of individual changeover activities between available workers.

\section{METHODOLOGY}

The whole case study is based on data from Filla (2014). The project was divided into three basic stages: a preliminary analysis, data collection, and the application of the SMED method. In the preliminary analysis several work measurement techniques, such as direct observation of the whole shift, were used, thus making it possible to describe the current situation on the shop floor. The most important outcome of the preliminary analysis was the justification of the project, i.e. proving that the application of the SMED method is essential for the company. The justification was based on Pareto analysis, whose aim was mainly to identify relevant downtimes during the shifts. The preliminary analysis was followed by the data-collecting stage, which was mainly based on video recording the largest possible number of changeovers. In the data-collecting stage it was essential to record different types of changeovers, and also to record different workers performing the changeover process. With the records it was possible to determine the complexity of individual changeovers, and also different approaches to the changeover process taken by individual workers. The final stage, the application of the SMED method, was based on Shingo's original SMED concept (1985), as described in Fig. 1. However, the application of the SMED method is slightly different because the distribution of the individual activities of changeover processes between multiple workers was needed in this specific case.

\section{PROBLEM FORMULATION}

The case study involves a flat glass processing company that has a variable production program and the need to optimize shop floor machine changeover processes. The justification of the whole project based on the Pareto analysis is shown in Fig. 2 below. Several techniques of work measurement, such as direct observation and a work sampling of the worker and machine during an entire shift, were used in the preliminary analysis phase. And the output of aforementioned analysis was used to determine summaries of individual downtimes. 


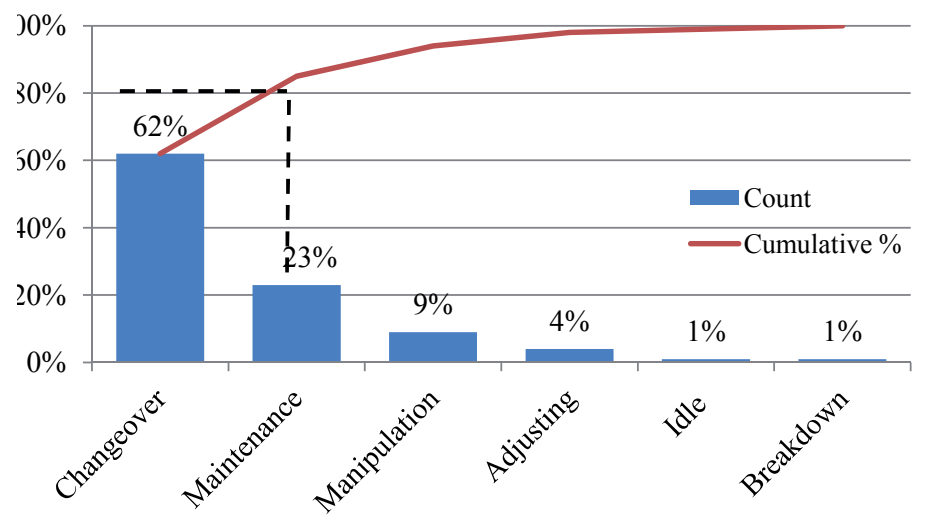

Fig. 2 - Pareto analysis - downtime (Filla, 2014)

The Pareto analysis shows the structure of various kinds of downtimes of the specific machine. According to the analysis, downtime is mainly caused by performing changeovers $(62 \%)$ and adjusting the machine equipment $(23 \%)$. Most of the machinery in the company is part of a production line that processes products that differ depending on the customers' diverse requirements. These requirements lead to a complex production plan with a high number of changeovers. Fig. 2 shows that conversion is a significant issue for the enterprise. For this reason, the company management decided to apply the method on a pilot workplace, i.e., the production line where the initial analysis took place. This line is considered a system bottleneck, and almost every product is processed on this machine. The company has several large customers who have ordered unique goods depending on their own production portfolio; as a result, there are several hundred product types with different characteristics are processed on the line.

\section{SOLUTION AND RESULTS}

\subsection{Dividing changeovers into groups according to their complexity}

The actual production line, which has been introduced above, consists of a material loader, grinding stations, drilling stations, a washer and conveyor belts which connect the various elements of the production line together. The line is operated by two employees - an operator and a worker who is responsible for the quality control of the final product. The changeover process is performed by the operator; the quality control worker does not participate in the changeover process of the production line. The primary purpose of this production line is to grind the edges and drill holes into the processed material. Due to a certain level of diversity in cases of individual changeovers, it was necessary to divide the production line into specific segments which determine the complexity of different types of changeovers. For the most accurate expression of the time needed for a specific type of changeover, four basic activities have been determined - changing the input material size, setting the software program, replacing the corner cutters and exchanging the drills. 
The activities have been identified as:

- S- changing the input material Size

- P - setting the Program

- D - exchange the Drills

- $\mathrm{C}$ - adjusting the Corner cutting machine

The specific sequences expressing the complexity of the individual type of changeover was determined. And all the types of changeovers are listed in the table (Tab. 1) below.

Tab. 1 - Specific types of changeovers (Filla, 2014)

\begin{tabular}{|c|c|c|c|c|c|}
\cline { 2 - 6 } \multicolumn{1}{c|}{} & $\begin{array}{c}\text { Changing the } \\
\text { input material } \\
\text { Size }\end{array}$ & $\begin{array}{c}\text { Setting the } \\
\text { Program }\end{array}$ & $\begin{array}{c}\text { Adjusting the } \\
\text { Corner cut- } \\
\text { ting machine }\end{array}$ & $\begin{array}{c}\text { Exchanging } \\
\text { the Drills }\end{array}$ & $\begin{array}{c}\text { Changeover } \\
\text { type }\end{array}$ \\
\hline 1. & $\bullet$ & $\bullet$ & $\bullet$ & $\bullet$ & SPCD \\
\hline 2. & $\bullet$ & $\bullet$ & & $\bullet$ & SPD \\
\hline 3. & $\bullet$ & $\bullet$ & $\bullet$ & & SPC \\
\hline 4. & $\bullet$ & $\bullet$ & & & SP \\
\hline
\end{tabular}

During the initial analysis of the changeovers, it was found that the durations of the two most time-consuming changeover variants, i.e., SPCD and SPD, are almost the same. For this reason these terms were dropped from the code designation and more user-friendly terms were adopted. Thus, the variants are now identified as small, medium and large changeover.

\subsection{Application of the SMED method}

The application of the method SMED was implemented based on the original procedure established by Shigeo Shingo (1985). The particular stages of the applications are named according to the steps which have been outlined in the text above (see Fig. 1). In the initial stages of the project the relevant data were collected. Primarily, the most complex types of changeovers were recorded. For the purposes of the project three conversions were reported, namely, there were two recordings of the SPCD changeover and one recording of the SP changeover. Furthermore, many additional recordings of individual operations, such as drill exchanges, adjustments to the corner cutting machine etc., were made. After analysing the collected data and distributing the various activities into groups in accordance with Shingo's methodology, it was discovered that all activities within the changeover process can be considered as internal operations in this particular case study. It was also discovered that several previous attempts to apply the SMED method or its parts had been made. Most of the solutions were undertaken before the start of the project and dealt with minor technical modifications of the machinery. In the changeover process several kinds of wastage was notice. The proportion of wastage to the total changeover time was approximately $10 \%$ in each changeover variant, which was also a part of the study. The only solutions to the given situation were to change the work organisation of the changeover process and the application of additional minor technical modifications to the machinery which had not been discovered and implemented during previous attempts to improve activities. Also, common 
techniques such as standardisation of operations were used and applied at the pilot workplace. Implementation of four phases of the SMED methodology is shown in table below (Tab. 2).

Tab. 2 - Implementation of four phases of the SMED methodology (Source: author's own)

\begin{tabular}{|c|c|c|}
\hline $\begin{array}{l}\text { SMED } \\
\text { method } \\
\text { conceptual } \\
\text { stages }\end{array}$ & Stage description & Stage implementation \\
\hline $\begin{array}{l}\text { Preliminary } \\
\text { stage }\end{array}$ & $\begin{array}{l}\text { Internal and } \\
\text { external setup not } \\
\text { distinguished }\end{array}$ & $\begin{array}{l}\text { Most complex types of changeovers were recorded } \\
\text { and the records were analyzed in accordance with the } \\
\text { SMED method. }\end{array}$ \\
\hline Stage 1 & $\begin{array}{l}\text { Separating the } \\
\text { internal and } \\
\text { external setups }\end{array}$ & $\begin{array}{l}\text { Internal and external setups were separated. There } \\
\text { were zero external operations, i.e. no part of the } \\
\text { changeover could be performed while the line was } \\
\text { operational. Internal setup involved mainly: } \\
\text { - adjustment of the loader } \\
\text { - exchange of the corner-cutting machine elements } \\
\text { - exchange and adjustment of the drills } \\
\text { - adjustment of the cooling system }\end{array}$ \\
\hline Stage 2 & $\begin{array}{l}\text { Converting the } \\
\text { internal setup to } \\
\text { external }\end{array}$ & $\begin{array}{l}\text { Because of the previous attempts to apply the SMED } \\
\text { method, many internal setup activities had been con- } \\
\text { verted to external ones in the past. }\end{array}$ \\
\hline Stage 3 & $\begin{array}{l}\text { Streamlining all } \\
\text { aspects of setup }\end{array}$ & $\begin{array}{l}\text { Minor technical and organizational modifications, } \\
\text { such as the labelling of individual elements of the line } \\
\text { or setting a new standard for drill exchange based on } \\
\text { the best experience, were proposed. }\end{array}$ \\
\hline
\end{tabular}

The most appropriate solution is to distribute the individual activities of the changeover process between the two workers who are available at the pilot workplace. Each operator is able to cover certain activities of the changeover process. It has to be noted that the distribution and synchronization of the activities has its limits. For example, when the tasks distributed to operator 2 have been completed but operator 1 is still performing his tasks, operator 2 is able to perform additional tasks that are not related to the changeover process. It also has to be mentioned that operator 2 has to finish his duties before he can take part in the changeover process. This method of distributing individual activities between two operators is shown in Table 3. 
Tab. 3 - Distributing individual activities between two operators (Source: own)

\begin{tabular}{|l|c|c|c|c|c|}
\hline $\begin{array}{l}\text { Operation } \\
\text { distributed to } \\
\text { operator 1 }\end{array}$ & $\begin{array}{c}\text { Duration } \\
\text { (mm:ss) }\end{array}$ & $\begin{array}{c}\text { Cumulative } \\
\text { time }\end{array}$ & $\begin{array}{c}\text { Cumulative } \\
\text { time }\end{array}$ & $\begin{array}{c}\text { Duration } \\
(\mathrm{mm}: \mathrm{ss})\end{array}$ & $\begin{array}{c}\text { Operation distrib- } \\
\text { uted to operator 2 }\end{array}$ \\
\hline $\begin{array}{l}\text { Loader shut } \\
\text { down }\end{array}$ & $02: 00$ & $02: 00$ & $02: 30$ & $02: 30$ & $\begin{array}{l}\text { Waiting for the end } \\
\text { of production run }\end{array}$ \\
\hline $\begin{array}{l}\text { Following } \\
\text { tasks }\end{array}$ & $05: 30$ & $07: 30$ & $10: 47$ & $08: 17$ & $\begin{array}{c}\text { Completion of re- } \\
\text { distributed tasks }\end{array}$ \\
\hline $\begin{array}{l}\text { Completion of } \\
\text { given tasks }\end{array}$ & $06: 17$ & $13: 47$ & $13: 47$ & $03: 00$ & $\begin{array}{c}\text { Additional tasks not } \\
\text { related to changeo- } \\
\text { ver }\end{array}$ \\
\hline \multicolumn{7}{|l|}{ Start of production } \\
\hline Total time & $13: 47$ & & & $13: 47$ & Total time \\
\hline
\end{tabular}

After the individual activities of the changeover process have been distributed between the two operators, a more visual method of the table above (Table 3) is needed. A visualisation of the changeover process performed by two operators is shown in Fig. 3 below. Both of these objects (Tab. 3 and Fig. 3) are simplified and are used only as an example of a proposed solution.

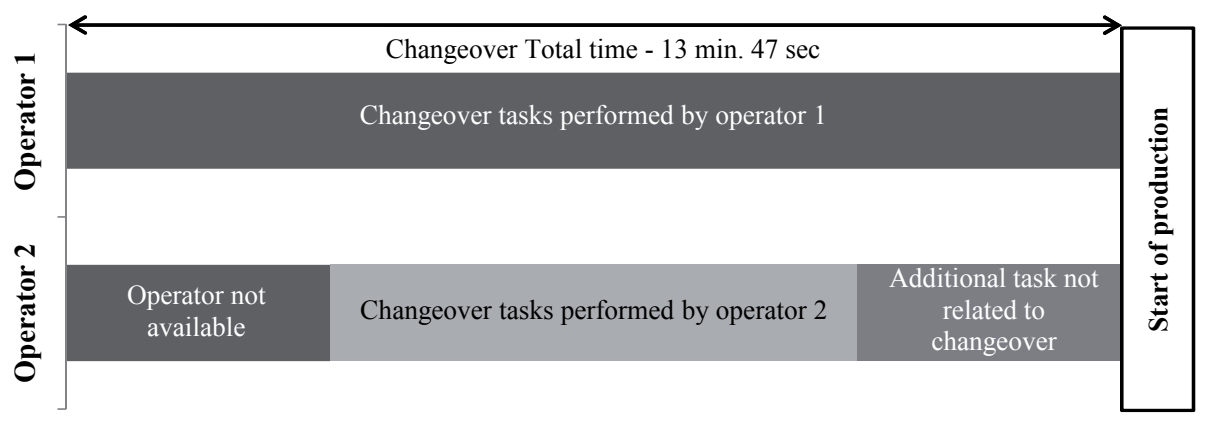

Fig. 3 - Changeover process visualization - simplified (Source: own)

For each type of changeover a similar solution was used and all of the managerial and work organization changes were also supported by proposing the application of additional industrial engineering methods such as 5S (Perinić, Ikonić, \& Maričić, 2009) and TPM (McIntosh et al., 2001).

\subsection{Results}

After the proposed corrective measures had been implemented and the compliance of the workers with the prescribed procedures had been ensured, the following values were reached. For reasons of confidentiality the original values are multiplied by a coefficient which is selected from the interval $<0.1>$, but all of the percentages reflect reality. The estimated savings obtained by applying the SMED method are shown below in Table 4 . 
Tab. 4 - Estimated savings of applying of the SMED method (Filla, 2014)

\begin{tabular}{|l|c|c|c|c|}
\hline Changeover type & $\begin{array}{c}\text { Duration before } \\
\text { SMED }\end{array}$ & $\begin{array}{c}\text { Duration after } \\
\text { SMED }\end{array}$ & Savings & Savings (in \%) \\
\hline Small C/O & $00: 16: 01$ & $00: 13: 04$ & $00: 02: 57$ & $18,43 \%$ \\
\hline Medium C/O & $00: 18: 00$ & $00: 13: 47$ & $00: 04: 13$ & $23,40 \%$ \\
\hline Large C/O & $00: 21: 53$ & $00: 15: 10$ & $00: 06: 43$ & $30,70 \%$ \\
\hline
\end{tabular}

Changeovers with a higher number of adjusted segments generally achieved savings of up to $30 \%$. It was also discovered that in cases of less complex changeovers, a lower percentage of time saved is achieved. This is mainly due to the fact that smaller numbers of activities cannot be reallocated between the two workers as effectively as in cases of highly complex changeovers. The savings of time are only approximately $18 \%$ and $20 \%$ for small and medium-sized changeovers. The ratio in which various kinds of changeovers occur at the selected workplace was identified from the information system and it is shown in Fig. 4 below.

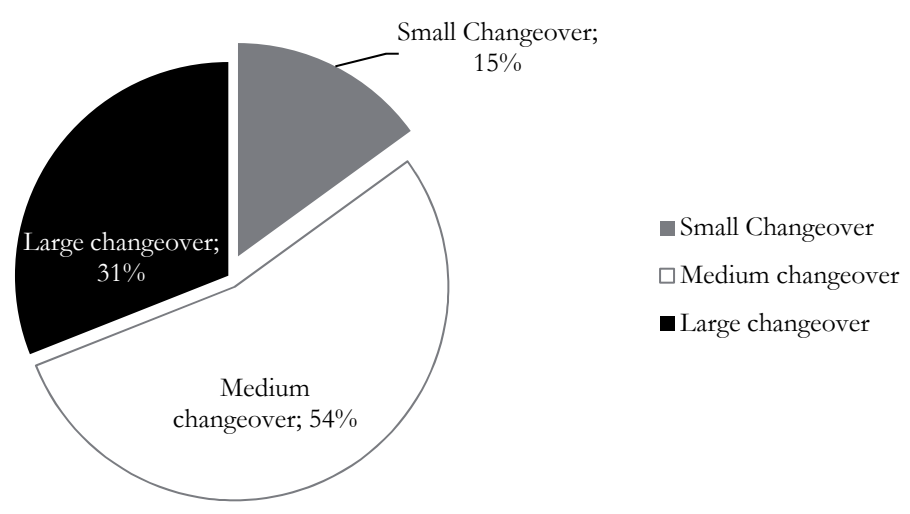

Fig. 4 - Changeover breakdown at the selected workplace (Filla, 2014)

On the basis of the structure of changeovers which are commonly performed at the selected workplace, the actual time period consumed by the changeovers in one year at the workplace was defined. A similar approach was used for determining the time period consumed by the changeovers after all of the corrective measures stemming from the application of the SMED method had been implemented. The calculations of the annual time savings are shown in the tables below (Tab. 5 and Tab. 6). For reasons of confidentiality the real values are multiplied by a coefficient which is selected from the interval $\langle 0.1\rangle$; the total amount of changeovers performed in the one-year period was set at a hypothetical value of 1000 changeovers per year. 
Tab. 5 - Annual time consumed by changeovers before SMED (Filla, 2014)

\begin{tabular}{|l|c|c|c|}
\hline $\begin{array}{l}\text { Changeover } \\
\text { type }\end{array}$ & $\begin{array}{c}\text { Duration before SMED } \\
\text { (in min.) }\end{array}$ & $\begin{array}{c}\text { Annual amount } \\
\text { of changeovers }\end{array}$ & $\begin{array}{c}\text { Annual time consumed } \\
\text { by changeovers }\end{array}$ \\
\hline Small C/O & 16 & 150 & 2400 \\
\hline Medium C/O & 18 & 540 & 9720 \\
\hline Large C/O & 22 & 310 & 6820 \\
\hline \multicolumn{2}{l}{} & 1000 & 18940 \\
\hline
\end{tabular}

Tab. 6 - Annual time consumed by changeovers after SMED (Filla, 2014)

\begin{tabular}{|l|c|c|c|}
\hline $\begin{array}{l}\text { Changeover } \\
\text { type }\end{array}$ & $\begin{array}{c}\text { Duration after SMED } \\
\text { (in min.) }\end{array}$ & $\begin{array}{c}\text { Annual amount of } \\
\text { changeovers }\end{array}$ & $\begin{array}{c}\text { Annual time consumed } \\
\text { by changeovers }\end{array}$ \\
\hline Small C/O & 13 & 150 & 1950 \\
\hline Medium C/O & 14 & 540 & 7560 \\
\hline Large C/O & 15 & 310 & 4650 \\
\hline \multicolumn{2}{r|}{} & 1000 & 14160 \\
\hline
\end{tabular}

$$
\text { The annual time savings }=1-\frac{\text { Annual time sonsumed by changeovers after SMED }}{\text { Annual time sonsumed by changeovers before SMED }}
$$

Annual time savings $=1-14$ 160/18 940

Annual time savings $=25.26 \%$

The annual time savings resulting from the application of the SMED method are approximately $25 \%$. It is highly probable that if additional investment is made, the result will be that much larger decreases in the time needed for processing changeovers will be seen.

\section{CONCLUSION}

The basic approaches of the application of the SMED method, which were defined by Shigeo Shingo, have been described in this article. The SMED method is mainly used to optimize the process of changeovers and for eliminating the negative impacts of frequent production programme changes, i.e., frequent setting and adjusting of machinery. In this case study the SMED method was implemented at a company with a high number of different manufactured products, which is currently quite common. However, in this case, the author is mainly focused on dividing changeovers into groups according to the complexity of the process itself. By using this kind of distribution, it is possible to use the data for a better evaluation of the savings stemming from the application of the SMED method. But according to the author, there is even greater potential in this way of applying SMED. The potential lies especially in integrating SMED methods with 
the information systems which are widely used in production companies. In cases in which a company is able accurately to determine the time required for a particular type of changeover, it should be possible to modify the sequence of orders in such a way as to meet the delivery times and also to reduce the total time required for changeovers. Cooperation between the SMED method and information systems has also been proposed by other authors (Cottyn et al., 2011; Palanisamy \& Siddiqui, 2013). According to the present author the potential for integration of the SMED method and information systems, such as MES, has not been fully discovered and documented yet, and it provides wide scope for further research.

\section{Acknowledgement:}

Author is thankful to the Internal Grant Agency of FaME TBU for financial support to carry out this research. The contribution was processed with the support from the project IGA/FaME/2016/004: Economics of quality and its impact on the efficiency of business processes and their parameters in Czech enterprises.

This paper is one of output of the RVO project RO/2016/03 "Modelling of parameters of effective production and administrative processes in industrial companies, based on the concept of Industry 4.0", realized by Faculty of Management and Economics, Tomas Bata University in Zlin

\section{References}

1. Bikram, J. S., \& Khanduja, D. (2009). SMED: for quick changeovers in foundry SMEs. International Journal of Productivity and Performance Management, 59(1), 98-116. doi: 10.1108/17410 401011006130

2. Cakmakci, M. (2009). Process improvement: Performance analysis of the setup time reduction-SMED in the automobile industry. International Journal of Advanced Manufacturing Technology, 41(1), 168-179. doi: 10.1007/s00170-008-1434-4

3. Cottyn, J., Van Landeghem, H., Stockman, K., \& Derammelaere, S. (2011). A method to align a manufacturing execution system with Lean objectives. International Journal of Production Research, 49(14), 4397-4413. doi:10.1080/00207543.2010.548409

4. Culley, S. J., Owen, G. W., Mileham, A. R., \& McIntosh, R. I. (2003). Sustaining changeover improvement. Proceedings of the Institution of Mechanical Engineers, 217(10), 1455 1470. doi: 10.1016/095440503322617225

5. Ferradás, P. G., \& Salonitis, K. (2013). Improving changeover time: A tailored SMED approach for welding cells. Procedia CIRP, 7, 598-603. doi: 10.1016/j.procir.2013.06.039

6. Filla, J. (2014). Projekt aplikace metody SMED ve společnosti SCHOTT Flat Glass cr, s.r.o. Univerzita Tomáše Bati ve Zlíně, Zlín.

7. King, P. L. (2009). Smed in the process industries. Industrial Engineer, 41(9), 30-35.

8. Mašín, I., \& Vytlačil, M. (2000). Nové cesty k vyšš̌ produktivitě: metody pruimyslovébo inžénýrství. 1. vyd. Liberec: Institut průmyslového inženýrství.

9. McIntosh, R., Owen, G., Culley, S., \& Mileham, T. (2007). Changeover improvement: Reinterpreting shingo's "SMED” methodology. Engineering Management, IEEE Transactions on, 54(1), 98-111. doi: 10.1109/TEM.2006.889070

10. McIntosh, R. I., Culley, S. J., Mileham, A. R., \& Owen, G. W. (2001). Changeover improvement: A maintenance perspective. International Journal of Production Economics, 73(2), 153-163. doi: 10.1016/S0925-5273(00)00170-5 
11. McIntosh, R., Culley, S., Gest, G., Mileham, T., \& Owen, G. (1996). An assessment of the role of design in the improvement of changeover performance. International Journal of Operations \& Production Management, 16(9), 5-22. doi: 10.1108/01443579610125552

12. Moxham, C., \& Greatbanks, R. (2001). Prerequisites for the implementation of the SMED methodology: A study in a textile processing environment. International Journal of Quality \& Reliability Management, 18(4), 404-414.doi: 10.1108/02656710110386798

13. Palanisamy, S., \& Siddiqui, S. (2013). Changeover Time Reduction and Productivity Improvement by Integrating Conventional SMED Method with Implementation of MES for Better Production Planning and Control. International Journal of Innovative Research in Science, Engineering and Technology, 2(12), 7961-7974.

14. Perinic, M., Ikonic, M., \& Maricic, S. (2009). Die casting process assessment using single minute exchange of dies (smed) method. Metalurgija, 48(3), 199-202.

15. Sharma, V. (2001). SMED for high-mix assembly. Circuits Assembly, 12(1), 62-68.

16. Sheri, C. T., \& Bohn, R. E. (2005). Setup time reduction for electronics assembly: Combining simple (SMED) and IT-based methods. Production and Operations Management, 14(2), 205-217. Retrieved from http://search.proquest.com/docview/ 228758338 ? accountid $=15518$

17. Shingō, S. (c1985). A revolution in manufacturing: the SMED system. Portland, Oregon: Productivity Press.

\section{Contact information}

Ing. Jan Filla

Tomas Bata University in Zlin

Faculty of Management and Economics

Mostni 5139, 76001 Zlin

Crech Republic

E-mail:filla@fame.utb.cz. 